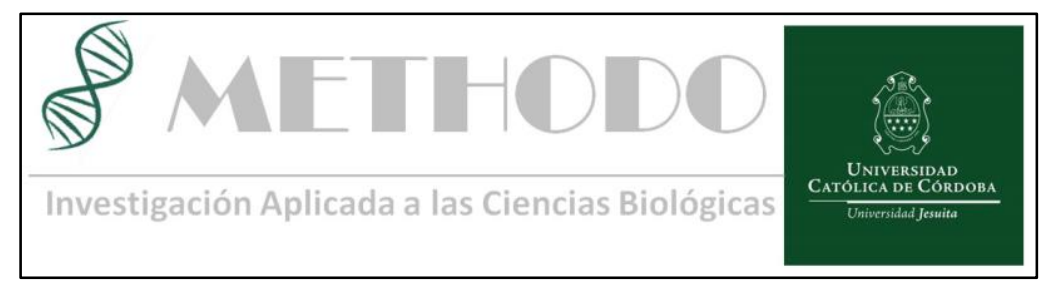

ARTICULO ORIGINAL Methodo 2017;2(2):65-67 DOI: $10.22529 / \mathrm{me} .2017 .2(2) 07$

Recibido 03 Dic 2016 | Aceptado 23 Abr 2017 | Publicado 30 Jn 2017

\title{
Prevalencia de fibrilación auricular paroxística en registros de holter de 24 horas realizados en Clínica Universitaria Reina Fabiola.*
}

\section{Prevalence of paroxysmal atrial fibrillation in Holter records of 24 hours performed in Clínica Universitaria Reina Fabiola*}

${ }^{*}$ Resumen deTrabajo Presentado en las XIII Jornadas de Investigación de la Clínica Universitaria Reina Fabiola- Diciembre de 2016

Galarza J ${ }^{1}$, Barcudi $\mathrm{R}^{1}$, Navia $\mathrm{M}^{1}$.

\section{RESUMEN}

Introducción: La fibrilación Auricular

Paroxística (FAP) es el tema central de este trabajo; su estudio es importante porque aumenta los riesgos de complicaciones tromboembolicas cerebrales, siendo estas las principales causas de mortalidad y morbilidad.

Objetivos: El objetivo principal del siguiente trabajo es evaluar la prevalencia de fibrilación auricular paroxística (FAP) en registros de Holter 24 hs y su relación con distintos factores de riesgo. EL objetivo secundario fue evaluar la relación de la FAP y sus complicaciones tromboembólicas cerebrales relacionándolas con diferentes variables.
Material y Métodos: Fueron revisados 960 Holter 24 hs consecutivos realizados desde enero del 2014 hasta diciembre del 2015 entre los que se identificaron 39 pacientes con FAP. Se analizaron los antecedentes patológicos y presencia de complicaciones tromboembólicas cerebrales. Los datos se consignaron en una ficha diseñada para tal fin y los resultados se expresaron con la media \pm DS para las variables cuantitativas y porcentajes para variables cuantitativas. Se consignó un valor de $p$ $<0,05$ para determinar significación estadística. Se utilizó el test estadístico CHI 2.

Resultados: La cantidad de pacientes con FAP fueron 39 (4\%) del total de estudios revisados, la edad promedio de los pacientes fue 67,92 (35-92)

Revista Methodo: Investigación Aplicada a las Ciencias Biológicas. Facultad de Medicina. Universidad Católica de Córdoba. Jacinto Ríos 571 Bo Gral. Paz. X5004FXS. Córdoba. Argentina. Tel.: (54) 351 4517299 / Correo: methodo@ucc.edu.ar / Web: methodo.ucc.edu.ar | ARTICULO ORIGINAL Methodo 2017;2(2):65-67 
Galarza J, Barcudi R, Navia M. Prevalencia de fibrilación auricular paroxística en registros de holter de 24 horas realizados en Clínica Universitaria Reina Fabiola. años, siendo la mayoría del sexo relating them to different variables.

masculino 26 (67\%). Las patologías de base fueron HTA 32 (82\%); DLP 25 (64\%); enfermedad vascular (EV) 15 (38\%); DBT 14 (36\%); IC 12 (31\%); tabaquismo 8 (21\%); 8 (21\%) eran obesos y valvulopatía 3 (8\%). De los pacientes con FAP, 11 (28\%) sufrieron eventos tromboembólicos cerebrales; de ellos6 (55\%) eran de sexo masculino. Nueve (82\%) padecieron ACV y $2(18 \%)$ CIT. Las variables asociadas a eventos tromboembólicos cerebrales fueron la edad mayor a 75 años ( $p$ 0.009) y el antecedente de EV (p 0.01).

Conclusiones: En este estudio la prevalencia de FAP en Registro de Holter de 24 hs fue del $4 \%$, más frecuente en el sexo masculino y con patología de base predominante la HTA\%. Se observó una alta prevalencia de eventos tromboembólicos cerebrales en pacientes con FAP que se relacionó significativamente con la edad mayor a 75 años y la presencia de EV.

\section{ABSTRACT}

INTRODUCTIONThe main target of the following work is to evaluate the AF predominance in records of $24 \mathrm{hs}$ Holter and its relation with different risk factors. The secondary target was to evaluate the relation betwen AF and brain tromboembolics complication

Material and Methods: 960 consecutive studies were checked realized from January, 2014 until December, 2015. 39 patients were included with $A F$, its case histories were checked seeing its pathological precedents and if they presented brain tromboembolics complication. The information was recorded in a card designed for such an end and the results SD expressed himself with the average \pm for the quantitative variables and percentages presented in the shape of graphs or stage as it should correspond. As statistical tool used the program SPSS v11. 0Sp. A value was recorded of $p<0.05$ to determine statistical significance in case of comparison between groups.

Results: The patients' quantity with $A F$ there were 39 that correspond to $4 \%$ of the checked studies, the age average of the patients was 67,92 years (35-92 years) being most of the masculine sex 26 (67\%). The base pathologies were a HBP 32 (82 \%); Dyslip 25 (64 \%); VD 15 (38\%); DM 14 (36\%); HF 12 (31 $\%)$; Tabaquic 8 (21\%); 8 (21\%) was obese and only 3 (8\%) Valvulopathies. Of the patients with AF, 11 (28\%) suffered brain tromboembolics events and 28 (72\%) was not affected; of those who had brain tromboembolic events it was of masculine sex 6 (55\%) and feminine $5(45 \%)$ in turn $9(82 \%$ 
Galarza J, Barcudi R, Navia M. Prevalencia de fibrilación auricular paroxística en registros de holter de 24 horas realizados en Clínica Universitaria Reina Fabiola. endured BTE and $2(18 \%) \mathrm{TCl}$ and the variables that marked a difference as per statistics significant as for brain tromboembolic events were the age oldest than 75 years ( $p$ 0.009) and the precedent of Vascular Illness ( $p$ 0.01) Conclusions: High AF predominance in Record of Holter of 24 hs was $4 \%$ more frequent in the masculine sex a $67 \%$ and that the pathology of predominant base was the hypertension in $82 \%$. High predominance of $28 \%$ of Brain tromboembolic events in patients with AF and that was related significantly to

Palabras claves: FIBRILACION AURICULAR, COMPLICACIONES TROMBOEMBOLICAS

Keywords: FIBRILLATION AURICULAR, TROMBOEMBOLICS COMPLICATION.

\footnotetext{
${ }^{1}$ Servicio de Cardiología, Clínica Universitaria Reina Fabiola, Universidad Católica de Córdoba, Argentina. Clínica Universitaria Reina Fabiola. Oncativo 1248 X5004FHP- Córdoba, Argentina.Correspondencia José Galarza e-mail: galarza73@yahoo.com.ar
} the age biggest than 75 years and the presence of Vascular Illness.

$\mathrm{AF}=$ Atrial Fibrillation, $\mathrm{SD}=\mathrm{Standard}$

Deviation, $\mathrm{HBP}=$ Hypertension, $\mathrm{VD}=$

Vascular disease, $\mathrm{DM}=$ Diabetes, $\mathrm{HF}=$ Heart failure, BTE= Brain

thromboembolic event, $\mathrm{TCl}=$ Transient

cerebral ischemia 